\title{
LUT
}

University

\section{Introduction: Presenting the Case for Studying the Emergence and Development of Family Business Groups}

Rosa Peter, Rautiainen Marita, Pihkala Timo, Parada Maria José, Discua Cruz Allan

This is a Final draft version of a publication

published by Palgrave Macmillan, Cham

in The Family Business Group Phenomenon

DOI: $10.1007 / 978-3-319-98542-8 \_1$

Copyright of the original publication: (c) The Author(s) 2019

Please cite the publication as follows:

Rosa P., Rautiainen M., Pihkala T., Parada M.J., Discua Cruz A. (2019) Introduction: Presenting the Case for Studying the Emergence and Development of Family Business Groups. In:

Rautiainen M., Rosa P., Pihkala T., Parada M., Cruz A. (eds) The Family Business Group Phenomenon. Palgrave Macmillan, Cham

This is a parallel published version of an original publication. This version can differ from the original published article. 


\title{
Introduction
}

\section{Presenting the case for studying the emergence and development of family business groups}

\author{
Peter Rosa, Marita Rautiainen, Timo Pihkala, Maria José Parada and Allan Discua Cruz
}

Richard Branson, perhaps the UK’s best-known entrepreneur, owns more than sixty different companies (www.virgin.com). There are Virgin companies operating in most areas of the world, covering a bewildering variety of sectors (financial services, health and wellness, music and entertainment, telecoms and media, travel and leisure). The only things that connect a company like Virgin Trains and Virgin Balloon Flights, for example, are the Virgin brand name and the ownership of Richard Branson. To decipher the full spectrum of Virgin companies and how they developed from Richard Branson's first venture in 1960 would be a complex and difficult exercise. Over the years, there are joint ventures, acquisitions, divestments, failures, as well as a consistent string of new ventures. Although Richard Branson appears as a lone entrepreneur heading the group, the Virgin website proudly proclaims the Virgin Group as “a family-owned growth capital investor”.

The Virgin Group is but one example of thousands of entrepreneur-founded family businesses that appear as single businesses in their publicity, but are in fact groups of legally independent businesses bound together by shared family ownership and management control. The most complex are large family businesses that have existed for several generations and which have developed sizeable business portfolios over the years. The Nurminen family in Finland, for example, has built up an extensive portfolio of companies since its origins in the late nineteenth century (Rautiainen 2012). Family business groups exist all over the world and appear to thrive in many different business environments and settings. Masulis, Pham and Zein (2011) in a broad cross-national study found that an average of 19 per cent of firms listed on the world's stock exchanges were family-owned or controlled business groups, and that the proportion was as high as 40 per cent in countries with emerging markets. Their study only referred to listed companies. There are many other large privately owned 
business groups not listed as public companies. As they are not listed on stock exchanges, their activities are less visible.

Since the 1970s, there has been considerable research on large business groups. Research has particularly centred on three core questions: Why do business groups exist? Does a business group structure enhance performance, and if so, in which context? Are the overall effects of business groups in the wider economy and society positive? Carney et al. (2011), in a meta-analysis of 141 research studies on business groups in 28 countries, have concluded 'that affiliation diminishes firm performance in general, but also that affiliates are comparatively better off in contexts with underdeveloped financial and labour market institutions ... Overall, our results indicate that affiliate performance reflects complex processes and motivations” (Carney et al. 2011: 437). A consensus has emerged on four issues (Carney et al. 2011):

1. That business groups are groups of firms which consist of a number of legally independent firms bound together by formal and informal ties and which are subject to coordinated action (Khana and Rivkin 2001).

2. That business groups commonly occur in all capitalist-based countries where larger firms are permitted and operate (Yiu, Bruton and Hoskisson 2007).

3. That there is a large diversity of forms of business groups, some of which, such as conglomerates, are more complex than the traditional multi-divisional form of corporate organization where a parent company owns and coordinates a group of smaller companies.

4. That business groups are especially common in developing countries where market failures, poor regulatory and legal institutions, and corruption encourage internalization of transactions and the spreading of risk through smaller legally independent companies rather than in one large unaffiliated one. Research on business groups in emerging markets has proliferated as emerging countries have grown in economic importance (Khanna and Palepu 1997; 2000 a,b; Yaprak and Karademir 2010).

A number of questions arise from the prevalence and complexity of large-scale business groups. How much diversity is there in the scale and nature of business groups, and how does this diversity 
reflect differing regulatory and market contexts in different sectors, countries and regions? How have complex business groups arisen, and why do they continue to persist and exist in a modern corporate business environment where the fashion has been a preference for concentration and specialization rather than unrelated diversification? How much more complex are family business groups than nonfamily corporate groups? Why do large family business groups vary in prevalence in different parts of the world? In particular, why do they seem more numerous in developing countries?

Large family business groups represent a low proportion of the total stock of family businesses, but in some countries they can account for a sizeable proportion of annual economic growth and job generation. In Uganda, for example, one family group alone, the Madvhani Group, are the largest private sector employers and taxpayers in Uganda (Balunywa 2009). Their 27 companies in Uganda are themselves part of a wider family conglomerate that operates in many other countries. The Sawiris family in Egypt is the largest private-sector contributor to its economy, with its global Orascom Group specialising in construction, telecommunications and tourism (Hatem 2011). In the Far East, family business groups such as Sony, Samsung, Mitsubishi and Alibaba are leading global companies. Even in the USA, what appear to be single corporations are, on closer inspection, entrepreneur-led business groups. The Microsoft Corporation, for example, has acquired 209 companies since its foundation, has divested 64, and has sizeable interests in 32 other companies.

It is our contention in this book that the 'complex processes and motivations' observed in many corporate business groups are greatly magnified where entrepreneurs and families are involved in the business. It is only recently that any attention has been paid to large family business groups (Masulis et al. 2011). The family business group researchers have begun to assess how far business group organisations are different in family firms, how far cross-cutting family motivations and ownership complicate the scale, nature and forms of a business group, and whether there are problems and advantages unique to family businesses in the way a business group is structured.

In every country, the largest number of businesses are small- to medium-scale family businesses, many of which are structured as small business groups. In their Scottish study, Rosa and Scott (1999) estimated that over a quarter of all businesses registered as companies were groups, funded by an entrepreneur or a family, and that nearly a fifth of partnerships were associated with more than 
one firm. In developing countries too, ownership of multiple enterprises has been observed to be common in the small- and micro-business sectors (McGaffey 1987; Kiggundu 2002; Rosa, Kodithuwakku and Balunywa 2006). Why are such families not concentrating on growing a single business rather than (apparently) dissipating their energies among two or more enterprises? What advantages does a small group have over a single venture? Is opting for a multiple enterprise organization more advantageous in some contexts than in others? How far do family ownership and goals complicate the management of a business group even at a small scale of operation? Put another way, does having family make it easier to delegate responsibility to family members when separate companies are started and developed from the core business?

The mainstream studies on business groups have focused almost exclusively on large-scale firms listed on the world's stock exchanges. There has been less attention paid to whether business groups are also relevant to non-listed businesses or to smaller businesses. Little of the mainstream management research on business groups, whether family-based or not, has considered how business groups are formed in the first place. How a business group has formed from small beginnings to its current complex form is a different question from why it continues to persist and thrive once a firm has reached a large size. To answer the question requires a more holistic approach, including the consideration of business groups in smaller (usually family) firms and even of the activities of individual entrepreneurs.

A growing volume of research on smaller entrepreneur and family business groups has been undertaken since the 1990s (reviewed by Ucsbasaran, Westhead and Wright 2008). These studies have demonstrated that the development of small business groups is driven mainly by entrepreneurial growth, in which entrepreneurs or entrepreneurial families grow their businesses by adding new ventures as new opportunities are accessed. This process has been termed 'portfolio entrepreneurship' (Birley and Westhead 1994; Scott and Rosa 1999; Rosa 1998). However, interest in portfolio entrepreneurship and smaller business groups, despite having burgeoned since the 1980s, is still a niche specialization within the broader field of entrepreneurship.

This entrepreneurship-based literature on portfolio entrepreneurship has developed in parallel to the mainstream management literature on business groups. On the one hand, management researchers 
investigating large-scale business groups have tended to assume that business groups are either nonexistent or at best embryonic in the small firm sector. As the portfolio entrepreneurship research has focused primarily on smaller firms, it has failed to attract the attention of mainstream management researchers on business groups. On the other hand, researchers on portfolio entrepreneurship, by focusing on smaller firms, have not accessed the mainstream business group research, as they may have perceived that most of the management literature on business groups may be less relevant in a smaller firm context (Iacobucci 2002). Interest in large-scale portfolio entrepreneurship (as displayed by entrepreneurs and families who have developed large business groups) is only a recent research development and is still at a pioneering stage. A number of empirical studies have been conducted since the late 2000s on large-scale portfolio entrepreneurs and large family business groups. These include Balunywa's (2009) and Malfense-Fierro's (2012) research on Ugandan and Malawi portfolio entrepreneurs, Hatem's (2012) research on the internationalisation of large-scale portfolio entrepreneurs and families in the MENA region, Rautiainen's (2012) analysis of large-scale Finnish family business groups, and Discua Cruz's research on family entrepreneurial teams in Honduras (Discua Cruz, 2010; Discua Cruz, Hamilton and Jack, 2012). These studies have demonstrated that portfolio entrepreneurship continues to play a significant role in the continued development and renewal of large business groups, particularly large family business groups. Its role is not confined to the early stages of business group development when the businesses were much smaller in scale.

During the development of research into business groups and portfolio entrepreneurship, family business researchers have pursued research agendas that have overlooked the existence or prevalence of family business groups. Instead, they have tended to concentrate their interests on family strategy and lifecycle issues such as long-term stewardship and orientation, overcoming problems of succession and family conflicts, and understanding the interface between business and family. Family business researchers have overwhelmingly treated and defined family businesses in their analyses as single firms, rather than as groups of businesses (Rosa, Howorth and Discua Cruz, 2014). In setting their research agendas, the complexities of family ownership, in particular, have not been prioritized. It is only in recent years that family business researchers have begun to take an interest in family business 
group structures, in trans-generational portfolio entrepreneurship and in the role of ownership in differentiating family business groups from non-family groups (Rosa et al. 2014)

In this book, we feel that understanding the formation, nature and complexity of family business groups requires a holistic understanding and integration of mainstream management business group research with research on portfolio entrepreneurship, trans-generational family business research, and family ownership. We demonstrate that 'business groups' exist in forms that are not just large scale, but also small scale and even rudimentary. At one extreme, micro-scale entrepreneurs form 'protogroups' of diversified very small and informal enterprises in response to new opportunities which could fall under the label 'pluriactivity', defined by Hetland as 'the diversification of activities carried out by one household on and off the holding, in order to secure the household's economy and welfare' (Hetland 1986, p. 385). Even at this micro-level, the importance of the family household, not the individual, as the unit of analysis has been stressed (Carter et al. 2004). At the other extreme are highly complex large trans-generational family business groups with over a hundred companies and intricate systems of ownership across many family members, including some non-family members. The neat well-organized multidivisional forms of business groups are contrasted by messy horizontal and loosely organized business groups when family groups are examined. Many family business groups reflect the outcomes of differing and often conflicting family business and ownership agendas and strategies, and it is these issues that make large family business groups more complex than corporate groups.

Therefore, a fuller understanding of family business groups requires not only blending and integrating these different strands of research, but also widening the scope of the research agenda to answer a greater range of questions. These would include the role of ownership in increasing the complexity of family business groups, to take a more holistic view of the field by discussing family business groups and portfolio entrepreneurship at different scales of size, different regional and industrial contexts, and to assess the overall contribution of family business groups to the economy and society. The structure of the book is designed to illustrate this wider perspective.

\section{The vision and organization of the book}


Considerable research on business groups in the management organizational fields, a growing interest in family business groups and a smaller body of research on portfolio entrepreneurship and smaller business groups have largely run parallel to each other and need to draw insights from each other. Placing greater emphasis on how family and portfolio entrepreneurship affect the emergence and persistence of business groups provides an opportunity to do this. Family business groups exist at all scales, from some of the largest business groups in the world to small proto-business groups in the small- and micro-business sectors. Each scale has fundamentally different specialist requirements for efficient and profitable business management, but family business groups have two things in common, irrespective of scale. They are associated with family ownership and family management to varying degrees and exhibit entrepreneurial behaviours and processes at all levels of scale.

The vision of the book is to further our understanding of the interaction of family and entrepreneurship in the development and management of business groups. Understanding this interaction is an area of research that has received little attention in either the mainstream management or entrepreneurship literatures. In attempting to achieve this, the book contains contributions addressing one of four themes:

\section{The theories and challenges of researching family-owned business groups}

(chapters 1 and 2). As a phenomenon, the family business group reflects characteristics that have been modelled within organization theory, strategic management and sociology. In Chapter 1, the theoretical basis for the understanding of the family business group phenomenon is covered. However, it seems evident that research on family business groups has been rather sparse. One of the reasons that family business groups have not been more extensively researched is because there are methodological challenges that researchers on non-family business groups do not encounter. Rosa, Rautiainen and Pihkala in Chapter 2 describe these challenges and summarize attempts made to try and overcome them.

\section{The emergence of business groups through portfolio entrepreneurship}

(chapters 3-6). As Granovetter (2005) noted, the emergence of business groups in general and the role of portfolio entrepreneurship in their emergence have not received much attention. This complex issue requires looking at their emergence at different scales and in different contexts. 
Rautiainen and Pihkala have spent some years researching large-scale family business groups in Finland. In Chapter 3, they examine through a single case study the emergence of a large family business group in Finland. Iacobucci and Rosa in Chapter 4 have concentrated on the emergence of a medium-sized family business group in Italy. In Chapter 5, Rosa, using Uganda cases, addresses the question of how some novice entrepreneurs start with minimal resources, yet eventually succeed in building large-scale family conglomerates. He illustrates how growth is achieved through a process of capital accumulation based on portfolio entrepreneurship, which he terms the 'entrepreneurial career ladder'. This is not just a process of trial and error; it is supported by an indigenous business culture within which portfolio entrepreneurship is an embedded practice. Finally, in Chapter 6, Akhter and Ning pose a similar question on how, amongst the poorest people in developing countries, pluriactivity, a survivalist necessity driven form of a proto-business group, can be transformed into a more positive and less necessitous state of existence (portfolio entrepreneurship). They demonstrate that resourcefulness, resilience, prior experience, family systems and social networks are key factors in achieving a positive state of portfolio entrepreneurship.

\section{Understanding how family introduces additional complexity into the development}

of family business groups (chapters 7-10). This section addresses a largely unexplored research issue: How do family factors such as transgenerational lifecycles, family ownership and family governance lead to business groups that are different and more complex than nonfamily business groups? In Chapter 7, Mukherjee, Rautiainen, Pihkala and Rosa draw on theories of complex adaptive systems to analyse family dynamics during an 18-year time slice of a long-lived Finnish family business group. They examine how complexity in business group development is influenced by differencing and conflicting goals and agendas of family members after a succession transition. The following three chapters (chapters 8, 9 and 10) focus on specific family factors and processes that affect the development and management of business groups. Parada, Basco, Discua Cruz, Fitz-Koch and Akhter examine family transgenerational entrepreneurship. They shed light on how next-generation family members engage in entrepreneurial activities, deploy resources, define their entrepreneurial orientation, 
transform family and business values, and adapt and reshape their business models as key dimensions for business group formation and existence. Pihkala, Goel, Rautiainen, Mukherjee and Ikävalko attempt to decipher the complexities of ownership of family business groups. They demonstrate that ownership, along with its multiple effects, may play a vital role in explaining the development and complexity of family business groups. Finally, under this theme, Goel, Ikäheimonen and Rautiainen identify family governance issues that affect the evolution, longevity and performance of family business groups.

\section{Family business groups and portfolio entrepreneurship operating in different}

local contexts. This final theme consists of three papers (chapters 11, 12 and 13). They illustrate how family business groups and portfolio entrepreneurship can be important despite operating in widely different local contexts. In the Finnish economy, innovation-led industries make a vital contribution. Konsti-Laakso, Heikkilä, Rautiainen, Rinkinen and Akhter study the role of family business groups for the regional innovation system. The present study is among the first to analyse the intellectual property rights (IPRs) filing activity by family business groups. Discua Cruz, Basco, Parada, Malfense-Fierro Alvarado examine resilience and family business groups in unstable environments. They present four case studies from Africa, Middle East and Latin America to showcase the diverse strategic responses of family business groups to cope with such an environment. In the last chapter (Chapter 13), Fitz-Koch, Cooper and Discua Cruz contribute to portfolio entrepreneurship research by showing that business groups can be the outcome of an emerging strategy that is aligned to family members' identities as well as the context in which they operate in. They illustrate this in a local family farming context.

The book concludes with an overview by the editors of its main empirical and theoretical contributions. It assesses how far the book's contributors have managed to achieve the aims of bringing together management and organization, entrepreneurship and family business perspectives to provide a holistic understanding of the emergence and development of family business groups. It also offers insights into how future researchers, practitioners and family business entrepreneurs and managers can benefit from the lessons that have emerged from the book’s authors. 


\section{References}

Birley, Sue and Paul Westhead. 1993. “A Comparison of new businesses established by 'novice’ and 'habitual’ founders in Great Britain.” International Small Business Journal, 12(1): 38-60.

Balunywa, Waswa. 2009. "Portfolio entrepreneurship and economic growth: the case of Uganda.” PhD thesis, University of Stirling, Scotland.

Carney, Michael, Eric R. Gedajlovic, Pursey P.M.A.R. Heugens, Marc Van Essen and J. (Hans) Van Oosterhout. 2011. "Business group affiliation, performance, context and strategy: A metaanalysis.” Academy of Management Journal, 54(3): 437:460.

Carter, Sarah, Stephen Tagg and Pavlos Demittritatos. 2004. "Beyond portfolio entrepreneurship: Multiple income sources in small firms.” Entrepreneurhip and Regional Development, 16(6): 481-499.

Discua Cruz, Allan. 2010. “Collective perspectives in portfolio entrepreneurship: A study of Honduran family business groups.” EDAMBA Journal, 2010 Thesis Competition, 8, 91-105.

Discua Cruz, Allan, Eleanor Hamilton and Sarah L. Jack. 2012. "Understanding entrepreneurial cultureees in family businesses: A study of family entrepreneurial teams in Honduras.” Journal of Family Business Strategy, 3(3): 147-161.

Hatem, Omaima. 2012. "High growth and rapid internationalisation of firms from emerging markets: the case of the Middle East and North Africa (MENA) Region.” Phd Thesis, University of Edinburgh, UK.

Hetland, Per. 1986. "Pluriactivity as a strategy for employment in rural Norway.” Sociologia Ruralis, XXVI (3/4): $385-395$.

Iacobucci, Donato. 2002. "Explaining business groups started by habitual entrepreneurs in the Italian manufacturing sector.” Entrepreneurship \& Regional Development, 14(1): 31-48.

Khanna, Tarun and Krishna Palepu. 2000a. "The future of business groups in emerging markets: Longrun evidence from Chile.” Academy of Management Journal, 43(3): 268-285.

Khanna, Tarun and Krishna Palepu. 2000b. "Is group affiliation profitable in emerging markets? An analysis of diversified Indian business groups”. Journal of Finance, 55(2): 867-891. 
Khanna, Tarun and Jan W. Rivkin. 2001. "Estimating the performance effects of business groups in emerging markets.” Strategic Management Journal, 22(1): 45-74.

Kiggundu, Moses N. 2002. "Entrepreneurs and entrepreneurship in Africa: What is known and what needs to be done.” Journal of Developmental Entrepreneurship, 7(3): 239-258.

McGaffey, Janet. 1987. "Entrepreneurs and Parasites, the Struggle for Indigenous Capitalism in Zaire.” Cambridge: Cambridge University Press.

Malfense Fiero, Antonio C. 2012. "Portfolio Entrepreneurs in Malawi: The Role of Risk and The Environment in the Process of Portfolio Creation and Growth." University of Edinburgh, $\mathrm{PhD}$ Thesis.

Masulis, Ronald W., Peter Kien Pham and Jason Zein. 2011. "Family business groups around the world: Financial advantages, control motivations and organizational choices.” Review of Financial Studies, 24(11): 3556-3600.

Rautiainen, Marita. 2012. "Dynamic Ownership in Family Business Systems - A Portfolio Approach.” Acta universitatis Lappeenrantaensis 485, Lappeenranta University of Technology. ISBN 978952-265-292-8, ISBN 978-952-265-293-5 (PDF), ISSN 1456-4491 (Dissertation).

Rosa, Peter. 1998. "Entrepreneurial processes of business cluster formation and growth by 'habitual' entrepreneurs.” Entrepreneurship, Theory \& Practice, 22(4): 43-62.

Rosa, Peter and Michael Scott. 1999. "The prevalence of multiple owners and directors in the SME sector: implications for our understanding of start-up and growth.” Entrepreneurship and Regional Development, 11(1): 21-38.

Rosa, Peter, Sarath Kodithuwakku and Waswa Balunywa. 2006. "Entrepreneurial motivation in developing countries: what does 'necessity' and ‘opportunity' really mean?” Frontiers of Entrepreneurship Research, 26(20): 1 - 14.

Rosa, Peter, Carole Howarth and Allan Discua-Cruz. 2014. "Habitual and portfolio Entrepreneurship and the Family Business. In Melin, L. et al. (eds) The Sage Handbook of Family Business,

Scott, Michael and Peter Rosa. 1999. "Entrepreneurial diversification business cluster formation and growth.” Environment and Planning C., 17(5): 527-547. 
Ucbasaran, Deniz, Gry Agnete Alsos, Paul Westhead and Mike Wright. 2008. "Habitual Entrepreneurs.” Foundations and Trends in Entrepreneurship. 4:4. Now Publishers Inc, Hanover U.S.A.

Yaprak, Attila and Bahattin Karademir. 2010. “The internationalization of emerging market business groups: an integrated literature review.” International Marketing Review, 27(2): $245-262$.

Yiu, Daphne W., Yuan Lu, Garry D. Bruton and Robert E. Hoskisson. 2007. "Business Groups: An Integrated Model to Focus Future Research.” Journal of Management Studies, 44(8): 15511579. 